\title{
Population Briefs, Vol. 15, no. 3
}

Population Council

Follow this and additional works at: https://knowledgecommons.popcouncil.org/ series_newsletters_popbriefs How does access to this work benefit you? Let us know!

\section{Recommended Citation}

Population Briefs 15(3): New York: Population Council, 2009. 


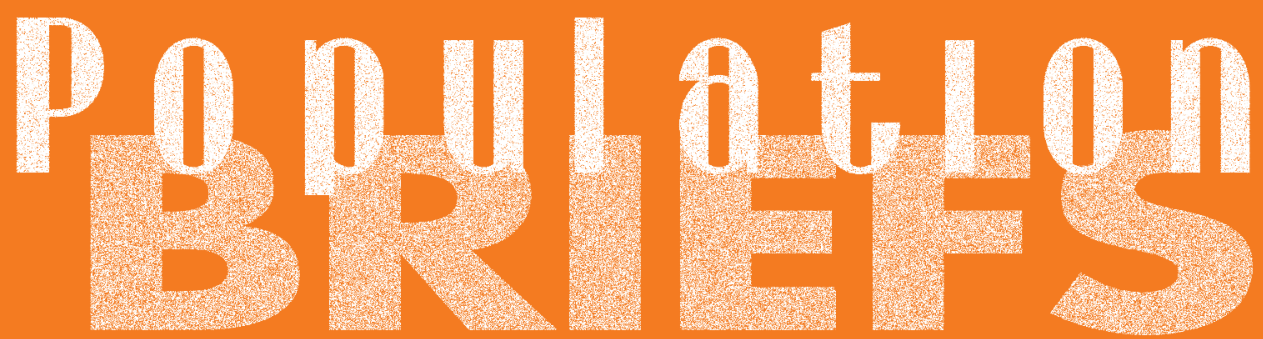

Reports on Population Council Research

December 2009 Volume 15, Number 3

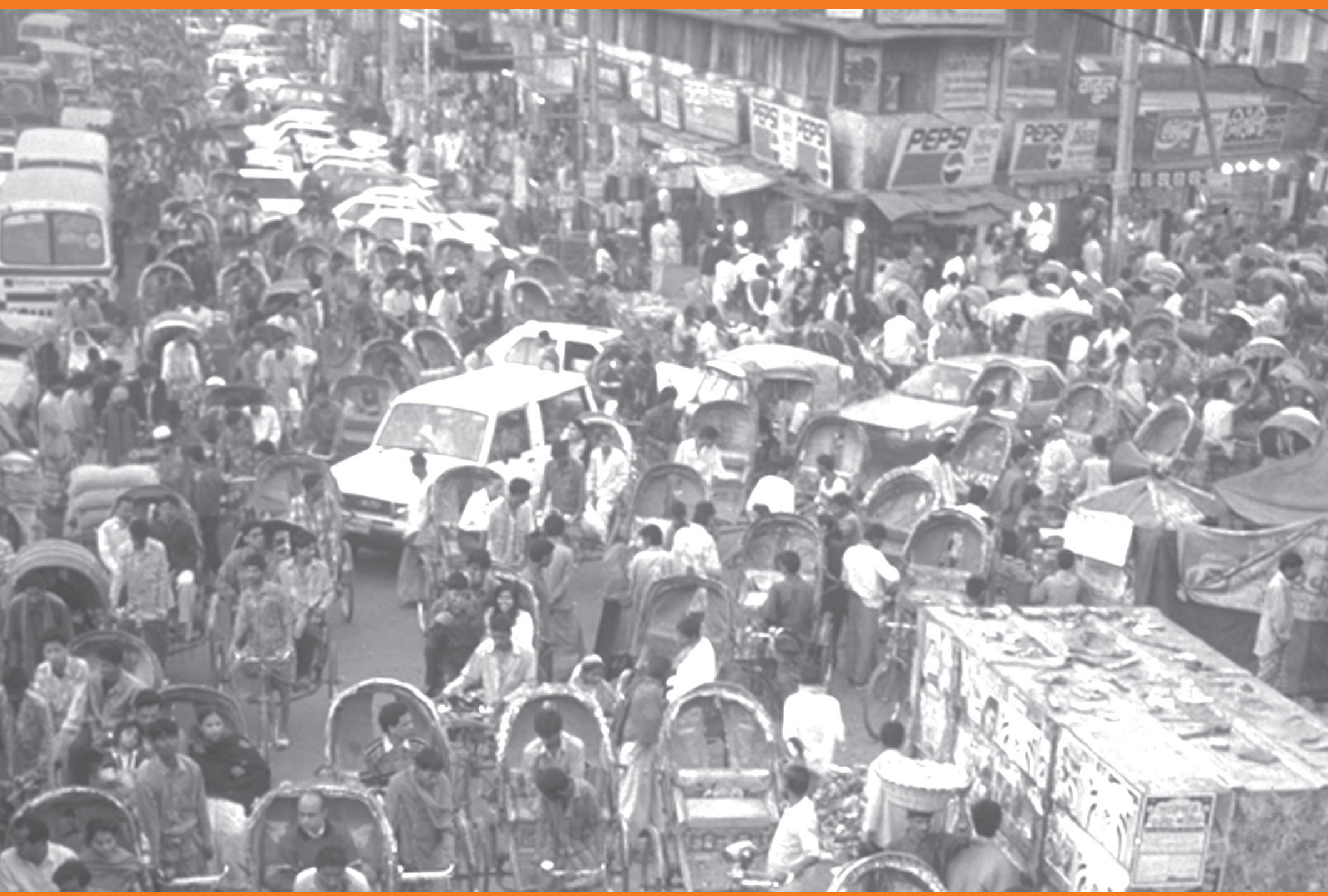

By 2030 each of the major regions of the developing world will hold more urban than rural dwellers.

See story, page 4.

I NS I DE

Despite Laws, Too Many Girls Marry Early .......................2

New Data Guides Bring Adolescents into Focus.................. 3

Urban Transformation Calls for New Approach

to Health Services

4

South African Program Promotes "Resilience" and Improves Post-Rape Care.

Attention to Neglected Postnatal Period Saves Lives ........... 7

Contraceptive Research Leads to an Array of Options..........8 


\section{Despite Laws, Too Many Girls Marry Early}

The health consequences of child marriage have been well documented: girls who marry at a very young age are more likely than women who marry after age 18 to experience early, frequent, and unplanned pregnancies, which raise the risk of complications and death during childbirth. Adolescent brides, some as young as 10, typically lack the skills to negotiate safe sex, placing them at increased risk for HIV and other sexually transmitted infections. Additionally, girls who marry early may stop attending school. Recognition of these threats, along with increasing acknowledgment of early marriage as a violation of girls' human rights, has led most countries to strengthen laws against child marriage — defined by UNICEF as marriage before age 18 .

Yet in many countries, especially in South Asia and sub-Saharan Africa, the laws are poorly enforced, and more than 100 million girls under age 18 are expected to marry in the next decade. These girls, and the 60 million girls under age 18 worldwide who are already married, need support and information.

In India, where the legal age for marriage was increased from 12 to 18 in 1978, the prevalence of child marriage remains unacceptably high, say the authors of a paper in the May 30 issue of The Lancet. In the study, Population Council demographer Niranjan Saggurti and colleagues from Boston University School of Public Health, the Harvard School of Public Health, and the Indian Council for Medical Research use data from India's 2005-06 National Family Health Survey to document the country's prevalence of child marriage.

\section{Early marriage often leads to high fertility}

Although data suggest that early marriage in India is slowly decreasing, with a 5 percent reduction since 1999, the authors' analysis shows that some 45 percent of Indian women aged 20-24 years were married before age 18 . Rural, poor, less educated girls and those from the central and eastern regions of the country were most likely to have married early.
Child marriage affects not only adolescents aged 16-17, but also large numbers of pubescent girls aged 14-15, they note. "The numbers suggest that neither recent economic progress nor policy gains or programmatic efforts to prevent child marriage have been sufficient to reduce the prevalence of child marriage in India to levels found in most other developing nations," Saggurti says.

The researchers also found an association between early marriage and reduced contraceptive use, multiple unwanted pregnancies, terminated pregnancies, and repeat childbirths less than 24 months apart.

For women who married as children, the median age at first childbirth was 17 years, while women who married as adults had a median age at first childbirth of 20 . Women married as children were more likely to have had three or more children and a repeat childbirth in less than 24 months than were those who married as adults.

\section{Council programs target social, economic, and bealth needs}

These findings underscore the need to address the underlying causes of child marriage. While programmatic efforts should be centered on women's needs, the authors add that husbands and in-laws must be included since in some cases they are the ones who make decisions about family planning. A Council initiative known as the First-time Parents Project, undertaken in partnership with Deepak Charitable Trust in Vadodara and the Child In Need Institute in Kolkata, shows how programs can empower these girls by working within their communities. Designed to boost girls' reproductive health knowledge and increase their ability to act in their own interests, the project had significant, positive effects on girls' autonomy, reproductive health knowledge and practice, and couple relations. "Our findings are very encouraging - both in exerting significant effects on the lives of married girls and in demonstrating the feasibility of implementing a program for this vulnerable population of girls," notes Nicole Haberland, a researcher in the Council's Poverty, Gender, and Youth program.

Other Council projects aim to improve educational and job opportunities for girls in rural areas so that child marriage is not the only economically feasible and socially acceptable option for many impoverished families. For example, in the Amhara region of Ethiopia, where rates of child marriage are among the highest in the world and half of all girls marry before their 15th birthday, a project is underway to promote girls' functional literacy, life skills, reproductive health education, and opportunities for saving money. Economic incentives encourage families to allow their daughters to participate in girls' groups that meet five days per week, and to remain in school. An evaluation of the project, called Berhane Hewan, found that significantly fewer girls in the experimental area had been married during early adolescence compared to girls of similar age in the control site.

Similar Council projects are underway in Bangladesh, Guatemala, India, Kenya, Nigeria, and elsewhere.

\section{SOURCES}

Amin, Sajeda, Erica Chong, and Nicole Haberland "Programs to address child marriage: Framing the problem," Promoting Healthy, Safe, and Productive Transitions to Adulthood Brief no. 14. New York: Population Council. (updated January 2008)

Raj, Anita, Niranjan Saggurti, Donta Balaiah, and Jay G. Silverman. 2009. "Prevalence of child marriage and its effect on fertility and fertility-control outcomes of young women in India: A cross-sectional, observational study," The Lancet 373(9678): 1883-1889.

Santhya, K.G., Nicole Haberland, Arup Das, Aruna Lakhani, F. Ram, R.K. Sinha, Usha Ram, and S.K. Mohanty. 2008. Empowering Married Young Women and Improving Their Sexual and Reproductive Health: Effects of the First-time Parents Project. New Delhi: Population Council.

\section{OUTSIDE FUNDING}

The Andrew W. Mellon Foundation, The Community Foundation for National Capital Region, Indian Council for Medical Research, The John D. and Catherine T. MacArthur Foundation, The Summit Foundation, The Turner Foundation, Inc., UK Department for International Development, United Nations Children's Fund (UNICEF), United Nations Population Fund (UNFPA) U.S. National Institutes of Health, The William and Flora Hewlett Foundation 


\section{New Data Guides Bring Adolescents into Focus}

Whe and advocats olds (and sometimes beyond), often turning to Demographic and Health Surveys (DHS) as a key source of data on this population. Long considered the gold standard of demographic data sets, the DHS present a vast range of demographic indicators from more than 70 countries. By measuring everything from vaccination rates in Nigeria to the frequency of domestic violence in Haiti, DHS data help demographers gauge a population's health, education, economic status, and more.

The difficulty, however, for users of the DHS and most other internationally comparable sources is the breadth of definition of youth in ways that submerge the adolescent experience. "'Youth' can apply to a period of two and a half decades — beginning as young as age 10 and extending as old as 35-rendering it too indefinite to be useful," explains Population Council policy analyst Judith Bruce. "The DHS data are normally analyzed from age 15 and on - which is particularly consequential for girls, whose puberty begins roughly two years earlier than it does for boys," notes Bruce. "The whole field has suffered from imprecise nomenclature and a related data vagueness, making it almost impossible to evaluate programs." She would prefer to drop the term "youth" entirely and focus instead on specific subsets and narrower age ranges very young adolescents for example, aged 10-14, or older adolescents, aged 15-19. Rather than five-year cohorts, sometimes even ten, she would like to have data on much narrower age groups, especially for younger adolescents.

As a senior associate with the Population Council's Poverty, Gender, and Youth program, Bruce and her colleagues have been presenting data to assist in designing evidence-based, targeted programs for adolescents, with an emphasis on the most vulnerable individuals. The focus on vulnerability drives the analysis toward the younger ages. "If you analyze the very worst things that happen to girls, you'll find that they happen very early, typically before age 15," she says. "Early marriage, female genital cutting, early pregnancy —all of these are human rights violations that happen early, as young as age 10 , and they damage reproductive health. We need to reach these girls early enough to make a difference in their lives: before they are forced to become sexually active," Bruce explains, adding that limitations in currently available data make it difficult to target these younger adolescents.

\section{Guides focus attention on}

\section{the most vulnerable}

Now, thanks to a new series of publications from the Population Council and the United Nations Population Fund, advocates and policymakers can employ a refined set of data, based on the DHS, to help them better tailor their initiatives to identify and reach these vulnerable younger adolescents. "The Adolescent Experience In-depth" offers insight into the status of young adolescents in 49 countries. Designed as a user-friendly tool for governments, UN country teams, nongovernmental organizations, and advocates, the series contextualizes data from the most recent Demographic and Health Surveys and includes charts and graphs to frame the information in a way that makes it easy for advocacy groups to raise awareness about the needs of young people.

"We've disaggregated the data and presented a lot of topics that are not in the DHS final reports or cross-tabulations," says Adam Weiner, a Council staff associate who worked with two assistants to compile the data over the course of a year. "By breaking the data down to focus on subgroups of adolescents, we highlight the diversity and point out which groups of young people are the most vulnerable. Our research reveals the tremendous variation among different subgroups."

"For instance, many reproductive health advocates focus on late adolescence and early womanhood, assuming that preadolescent girls are a relatively stable population —in school and supported by parents. The platforms of many programs are thus set in schools and seek to engage parents," Weiner explains. "Yet an analysis of the data reveals that a surprisingly high proportion of adolescents, particularly those in the lowest two economic quintiles, don't attend school and a significant percentage are living with one or no parents, even at that young age."

As children between ages 10 and 14 approach adolescence, they take on greater responsibility in the home, Bruce elaborates. Girls, especially, face societal pressures to leave school, marry, have sex, and bear children. Boys in this

"If you analyze the very worst things that happen

to girls, you'll find that

they happen very early,

typically before age 15.

age group who are out of school are also at high risk. "These very young boys and girls are the least likely to seek out and receive social and health services and, paradoxically, so too are the youngest first-time mothers, who are often the victims of child marriage," Bruce notes. "These most vulnerable individuals require a proactive set of policy prescriptions to prevent or mitigate their exploitation."

The Council publications present the data in a way that tells an intelligible story about young people, supplementing DHS data with a host of other sources, such as UNICEF's Multiple Indicator Cluster Survey, the United Nations' Millennium Project, the World Bank's Living Standards Measurement Study, research by Council staff, and other sources.

\section{SOURCE}

"The Adolescent Experience In-Depth: Using Data to Identify and Reach the Most Vulnerable Young People": Multi-Country Series. New York: Population Council, 2009.

\section{OUTSIDE FUNDING}

United Nations Population Fund 


\section{Urban Transformation Calls for New Approach to Health Services}

According to the latest projections by the United Nations Population Division, by 2030 each of the major regions of the developing world will hold more urban than rural dwellers, a development known as the urban transformation. Asia and Latin America already have several cities above 10 million in population, and in recent decades hundreds of large cities, each with populations exceeding one million, have emerged throughout the developing world.

As they explore the wide-ranging social, economic, and political implications of the urban transformation, economists are hampered by a limited set of forecasting tools. New research by Population Council demographer Mark Montgomery aims to refine the data by applying new, spatially sensitive methods for estimating and projecting urban populations, paying close attention to where the urban poor are located within and across cities. His findings, summarized in a special section of the journal Science and as a chapter in a forthcoming book on climate change, analyze the health risks and benefits of urban living and dispel some of the assumptions surrounding urban poverty.

\section{Is there really an urban bealth advantage?}

"There's a common belief that urban dwellers are generally healthier than rural residents, in part because there are more health and social services in cities," Montgomery notes. For instance, one analysis of 90 Demographic and Health Surveys found that, on average, the urban populations of poor countries exhibit lower levels of child mortality than their rural counterparts. Similar urban/rural differences surface across a range of health indicators. "However, averages can be a misleading basis on which to set health priorities," Montgomery explains. "Once we break down the data, it is clear that the urban poor often face health risks that are nearly as severe as or even worse than those of rural villagers."
According to Montgomery, who distinguishes between "slum dwellers" and the "urban poor," much more needs to be done to determine the percentage of the urban poor living in slums. For example, one study of urban India found that of all urban households officially classified as poor in 2005, over 80 percent were in nonslum neighborhoods. Also, slums may contain significant percentages of households whose expenditures would put them above the official poverty line. "With-

\section{In recent decades}

bundreds of large cities,

each with populations

exceeding one million,

have emerged through-

out the developing world.

out this information, it is not clear whether poverty alleviation programs should target poor places, such as slums, or poor people, who may live in a variety of neighborhoods," Montgomery says.

Montgomery's work attacks another myth: that most urban residents live in huge urban agglomerations, or megacities, with populations of more than 10 million. In fact, of all urban residents in cities of 100,000 and more in the developing world, only about 12 percent, or 1 in 8 urban residents, live in megacities. The majority of urban dwellers live in smaller cities or towns. "The demographic literature tends to overstate the role of very large cities and underemphasize the importance of small- and medium-sized cities," Montgomery concludes.

\section{Natural population growth rate versus migration}

When confronted with rapid urbanization, many governments try to expel slum residents and discourage further migration to densely packed urban neighborhoods. This response is likely based on another myth: that migration accounts for most of the urban growth. In developing countries about 60 percent of the urban growth rate is attributable to natural growth - the difference between birth rates and death rateswhile the remaining 40 percent is due to migration and spatial expansion. Therefore, a better approach to controlling urban growth might be to promote voluntary family planning programs and work with government health agencies and advocacy groups to improve services to the poorest urban areas, Montgomery suggests.

\section{Urban bealth risks are often unacknowledged}

According to Montgomery, these and other misconceptions have led policymakers to neglect several key areas, especially in the health field. In many countries residents of smaller cities go without adequate supplies of drinking water and minimally acceptable sanitation. Likewise, while rural shortages of health personnel and services have received attention in recent literature, similar shortages also plague smaller cities and towns. Conventional poverty measures also ignore the important factors of crime and violence, risks that threaten many city dwellers. Indoor and outdoor air pollution, as well as injuries and deaths stemming from traffic accidents, also plague the urban poor. In a bulletin published this summer by the Population Reference Bureau, Montgomery enumerates many "underappreciated" health risks facing the urban poor:

- Calling mental health a "central factor in the health of the urban poor," Montgomery notes that community-based studies of mental health in poor countries suggest that 12 percent 
to 51 percent of urban adults suffer from some form of depression.

- Violence in urban areas takes a variety of forms, ranging from political and extrajudicial violence to gang violence, local violent crime, and domestic abuse.

- Although as a group urban women are more likely than rural women to use contraception, poor urban women face disadvantages not unlike those facing rural women. The fact that modern contraceptives are often more readily available in urban areas than in rural regions does not imply that poor urban women will be able to use them effectively. Many poor urban women have an unmet need for modern contraception. These women may want to prevent or delay their next birth, yet for various reasons they do not use modern methods to achieve their stated aims, or they use contraception inconsistently or improperly.

- When it comes to HIV/AIDS, there is little evidence of the "urban advantage" that is seen for other health conditions. Community-based studies of HIV prevalence are now available for a number of developing countries. In at least three cases — Kenya, Mali, and Zambia - urban prevalence rates are much higher than rural rates.

- Although malaria has often been regarded as a rural disease, and rural rates of transmission are higher than urban rates, there is evidence that malaria vectors have adapted to urban conditions in sub-Saharan Africa and in some parts of Asia. In urban sub-Saharan Africa, some 200 million city dwellers face appreciable risks of malaria.

- Although data are scarce, it is likely that detection rates of tuberculosis among the urban poor are well below rates for other urban residents.

- Recent estimates suggest that more than 2 billion people worldwide rely on solid fuels, traditional stoves, and open fires for their cooking, lighting, and heating. These fuels — often used by the urban poor — generate harmful gases that are believed to substantially raise the risks of acute respiratory infections and chronic obstructive pulmonary disorders.

\section{New data analysis leads to a better approach}

By relying on new databases, such as the Global Rural Urban Mapping Project (GRUMP), part of

Estimates of urban and rural prevalence of HIV: Kenya, Mali, and Zambia

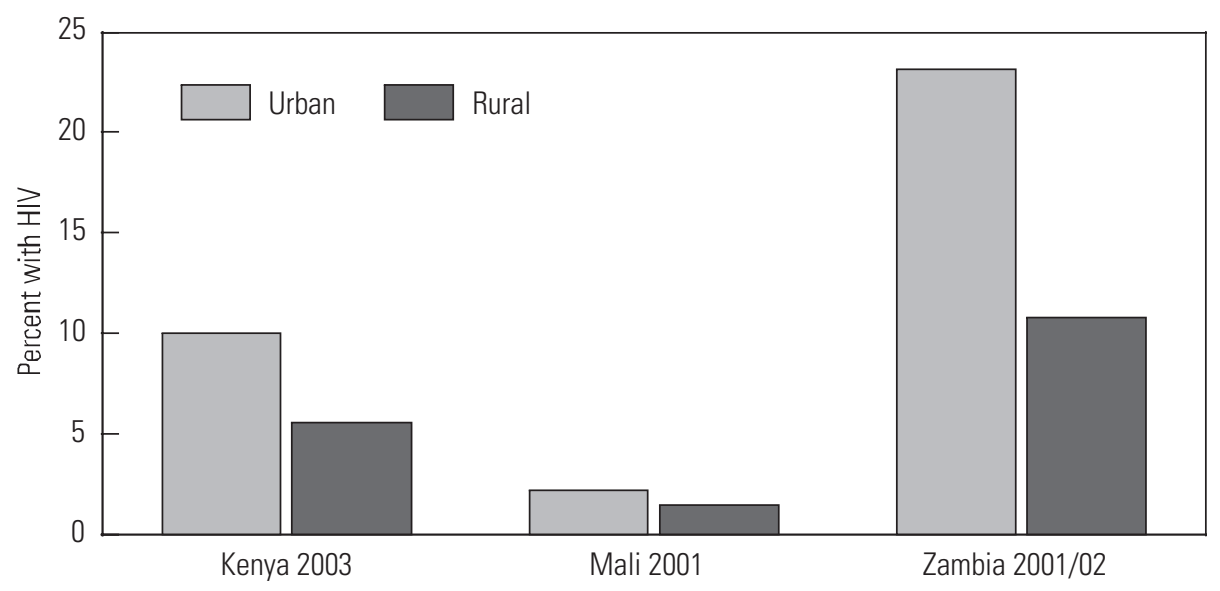

Sources: Mali Ministère de la Santé, Enquête Démographique et de Santé Mali 2001 (Ministère de la Santé Mali and ORC Macro, 2002); Kenya Central Bureau of Statistics, Kenya Demographic and Health Survey 2003: Preliminary report, and Zambia Central Statistical Office and ORC Macro, Zambia Demographic and Health Survey 2001-2002.

Columbia University's Earth Institute, Montgomery has uncovered subtle new patterns in urban population projections. GRUMP is one of the first efforts to combine satellite mapping data with population census information. This combination has led to new insights into the distribution of human populations across ecosystems, as well as into changes in patterns of rural and urban development.

"Perhaps the greatest need on the demographic front is to ensure that the censuses in developing countries are analyzed at the level of small geographic units and the results placed in the hands of the local and municipal governments," Montgomery suggests. "The data can be an effective tool in planning the pace and spatial distribution of future growth." Remotesensing methods, such as satellite mapping, can serve as a valuable supplementary tool.

While geographic targeting may be an effective health strategy for reaching slum dwellers, other approaches will need to be devised to meet the needs of the poor who live outside slums, Montgomery suggests. "The public health sector needs to work in tandem with other government agencies," he says. "Munici$\mathrm{pal}$, regional, and national governments need to join forces and form partnerships with private for-profit and nonprofit groups."

As an example of successful partnerships, Montgomery points to grassroots savings groups, which in some cases have collaborated with nongovernmental organizations to improve local sanitation and water supply systems, pro- viding public toilets in Mumbai and extensions of water and sewer lines in Karachi. According to Montgomery, the changes need not be big to make a difference. In Mexico, for example, a program that replaced dirt with cement floors significantly improved the health of young children, leading to reductions in rates of parasitic infection, diarrhea, and anemia.

"Among all the misconceptions that have hindered work on urban health, perhaps the most pernicious is the view that in contrast to rural villages, urban neighborhoods somehow lack the social cohesion needed to sustain community participation," Montgomery concludes. "In an urbanizing era, there is every reason to design health programs for the urban poor that take full advantage of the social resources and resourcefulness of their communities."

\section{SOURCES}

Balk, Deborah, Mark R. Montgomery, Gordon McGranahan, Donghwan Kim, Valentina Mara, Megan Todd, Thomas Buettner, and Audrey Dorelien. 2009.

"Mapping urban settlements and the risks of climate change in Africa, Asia and South America," Chapter 5 in José Miguel Guzmán, George Martine, Gordon McGranahan, Daniel Schensul, and Cecilia Tacoli (eds.), Population Dynamics and Climate Change. New York: United Nations Population Fund and International Institute for Environment and Development, pp. 80-103.

Montgomery, Mark R. 2008. "The urban transformation of the developing world," Science 319 (5864): 761-764.

Montgomery, Mark R. 2009. "Urban poverty and health in developing countries," Population Bulletin 64 (2): 1-16.

\section{OUTSIDE FUNDING}

The William and Flora Hewlett Foundation 


\section{South African Program Promotes "Resilience" and Improves Post-Rape Care}

The prevalence of rape in South Africa presents a daunting public health challenge. According to a June 2009 study by the South African Medical Research Council, as many as a quarter of all men surveyed admitted to raping a woman or girl. In many cases the attacks happen to children under age 13 . The health consequences are significant: in addition to the immediate physical injury and psychological trauma, rape survivors often suffer long-term consequences such as depression, post-traumatic stress disorders, and gynecological disorders, and are at risk of unwanted pregnancy and sexually transmitted infections (STIs), including HIV.

A Population Council-supported program known as Refentse - meaning resilience in the face of adversity — demonstrates how a rural hospital can improve post-rape care by training nurses to provide integrated medical-care management for rape survivors. The improvements, which cost little to implement, strengthen and link established services and decentralize care from doctors to nurses. Results of the study were described in a recent issue of the British Medical Journal.

\section{Good care requires quick response}

In part because of the violent and invasive nature of sexual assault, health care professionals in both industrialized and developing countries face many challenges in providing timely and comprehensive post-rape services. In addition to immediate medical attention for physical injuries, rape survivors require various therapeutic, social, and legal services, including post-exposure prophylaxis (PEP) for HIV and other STIs, emergency contraception, and trauma counseling. Administration of HIV PEP, which provides the only option for protecting against HIV infection following an assault, is especially challenging: to be most effective, PEP must be started within 72 hours of exposure. Many practitioners lack an adequate understanding of how to administer PEP in the context of sexual assault, and even fewer have well-developed strategies for ensuring adherence to the full 28-day course of treatment. Other important procedures such as emergency contraception to prevent pregnancy and the collection of forensic evidence for legal prosecution are also time-dependent.

Ian Askew, the Population Council's director of reproductive health services and research, and his colleagues from the Rural AIDS and Development Action Research Programme (RADAR), School of Public Health, University of the Witwatersrand in South Africa, initiated the Refentse program in 2003 at a 450-bed district hospital in a rural region in the country's northeast corner. The hospital functions as a referral center for surrounding clinics.

\section{New approach improves services, raises awareness}

The team set out to improve the quality of postrape care with a five-part intervention:

1. A sexual violence advisory committee, comprising hospital staff members, social workers, and local police, contributed to the study's design.

2. The committee drafted a rape management policy for the hospital that defined examination and treatment protocols and included both HIV counseling and testing and an immediate dose of PEP followed by a 28-day course of treatment.

3. A two-day training workshop for health professionals addressed the common myths and attitudes about rape, enhanced doctors' and nurses' clinical skills, and aimed to strengthen the relationships between the health sector and the police and judicial system. After the workshop, police officers decided to prioritize PEP treatment by bringing patients to the hospital immediately.

4. Senior nursing managers designated a room for post-rape care and stocked it with all necessary treatment supplies.

5. A public awareness campaign aimed at the local community disseminated information about sexual violence, its effects on health, and the services available at local clinics, and encouraged survivors of assaults to seek care immediately following an attack.

\section{An expanded role for nurses}

After the intervention the hospital's post-rape cases increased from eight to 13 per month, and the proportion of patients who saw six or more service providers on their initial visit decreased from 86 percent to 54 percent. Although these improvements did not result in a decline in the overall time spent at the hospital, patients' impressions of the quality of care improved substantially. On the other hand, patients' confidence in the police and judicial system did not change.

The study showed that nurses could play a key role in post-rape care. Following the intervention, their role was expanded to include documenting the rape, providing acute trauma counseling, and providing an immediate dose of HIV PEP. Nurses proved reluctant to perform the forensic examinations, which are needed to collect evidence, because they were intimidated by the prospect of presenting evidence in court.

"We were successful in introducing many small changes that had a big impact," Askew concluded. "With additional training and linking of existing services, nurses can become the primary providers of this care." The study's findings have helped inform recent international and national policies and guidelines on PEP throughout the region.

\footnotetext{
SOURCES

Jewkes, Rachel, Yandisa Sikweyiya, Robert Morrell, and Kristin Dunkle. 2009. "Understanding men's health and use of violence: Interface of rape and HIV in South Africa," South African Medical Research Council Policy Brief, June.

Kim, Julia C., lan Askew, Lufuno Muvhango, Ntabozuko Dwane, Tanya Abramsky, Stephen Jan, Ennica Ntlemo, Jane Chege, and Charlotte Watts. 2009. "Comprehensive care and HIV prophylaxis after sexual assault in rural South Africa: The Refentse intervention study," British Medical Journal 338 (b515): 1559-1562.

OUTSIDE FUNDING

US Agency for International Development, US President's Emergency Plan for AIDS Relief (PEPFAR)
} 


\section{Attention to Neglected Postnatal Period Saves Lives}

In Swaziland, a country with one of the highest rates of HIV infection in the world, the Ministry of Health and Social Welfare has tried to stem the spread of AIDS by adopting a package of methods proven to prevent mother-to-child transmission of HIV. Known collectively as PMTCT, these efforts include promoting HIV testing, offering advice on breastfeeding, and prescribing prophylactic antiretroviral drugs to HIV-positive pregnant women. Because 97 percent of pregnant Swazi women seek antenatal care at least once, the PMTCT program, which was linked to routine mother and child health care services in 2003, has helped improve the quality of antenatal care offered to pregnant women.

\section{First days after birth pose biggest risk for mothers and babies}

Yet despite the success in reaching women before they give birth, policymakers have paid little attention to the critical postnatal period. Both babies and mothers are especially vulnerable during the first few days after birth; worldwide, 75 percent of newborn deaths occur in the first week after birth, with half of these happening within the first 24 hours. More than 60 percent of maternal deaths occur within 48 hours of childbirth, yet in Swaziland women and their babies are typically discharged within 12 hours of delivery. Furthermore, the conventional recommendation for the first postnatal visit is at $4-6$ weeks after birth. By that time the most critical period has passed, and many of the maternal and newborn deaths have already taken place.

In a number of southern African countries, concern is growing that HIV is contributing to a higher number of maternal deaths due to postpartum sepsis or infection. Yet, the main threats to mothers are postpartum hemorrhage, sepsis, and eclampsia, all of which remain substantially unaddressed. For babies the main cause of death in the early neonatal period is not related to HIV. Practically all newborn deaths in this period are from asphyxia, sepsis, and complications of premature birth.
Population Council reproductive health research associate Charlotte Warren and a team of researchers from the Central Statistics Office and Swaziland's Ministry of Health (in conjunction with the Elizabeth Glaser Pediatric AIDS Foundation and the Basic Support for Institutionalizing Child Survival project) tested ways to take advantage of the link between PMTCT services and routine maternal and newborn health programs. They assessed the effectiveness of a new package of postnatal care in three hospital maternity units and four public health clinics. The team used interviews to gauge the knowledge and attitudes of mothers and health care providers; they checked hospital and clinic registers to determine how often clients used services; and they measured the skills of providers by observing client-provider interactions.

The baseline assessment identified several gaps in service, which were addressed by strengthening immediate care after birth (within the first six hours after delivery); recommending at least one daily exam during a woman's stay at the facility; and improving care and counseling at discharge, including scheduling a specific appointment for the first postnatal visit. The guidelines recommended that mothers return for a postnatal exam at both one and six weeks to receive improved counseling on maternal health, family planning, essential newborn care, and a review of selected issues related to management of HIV and AIDS.

\section{Early attendance at postnatal clinics jumps}

A pre- and post-test design allowed researchers to evaluate the effectiveness of the new postnatal service guidelines. After the introduction of the new package of postnatal care, postpartum women were three times more likely to return for a postnatal visit within one week of delivery. Providers' knowledge of essential newborn care also increased.

The researchers concluded that linking postnatal care with high-quality integrated PMTCT programs results in earlier postnatal vis- its and improved care for both HIV-positive and HIV-negative mothers and their babies. Further, they reported an increase in the proportion of postpartum women and their partners getting tested for HIV. The number of HIV-positive women and their exposed infants who started cotrimoxazole prophylaxis also increased.

A significant increase was seen in the proportion of mothers who breastfed their

Worldwide, 75 percent

of newborn deaths

occur in the first week

after birth.

babies within one hour of birth among both HIV-positive and HIV-negative women. There was also a significant increase in the proportion of HIV-negative mothers practicing exclusive breastfeeding.

By linking high-quality PMTCT programs with maternal and newborn health programs, policymakers can improve health care for both HIV-positive and HIV-negative mothers and their babies. The package of postnatal care relied heavily on training staff in new ways of organizing and providing services; according to researchers, the biggest obstacle in expanding the project is high staff turnover.

\section{SOURCES}

Mazia, G., I. Narayanan, C. Warren, M. Mahdi, P. Chibuye A. Waligo, P. Mabuza, R. Shongwe, and M. Hainsworth. 2009. "Integrating quality postnatal care into PMTCT in Swaziland," Global Public Health 4 (3): 253-270.

Warren, Charlotte, Rachel Shongwe, Allen Waligo, Mohammed Mahdi, Goldy Mazia, and Indira Narayanan. 2008. "Repositioning postnatal care in a high HIV environment: Swaziland," Horizons Final Report. Washington, DC: Population Council.

\section{OUTSIDE FUNDING}

Elizabeth Glaser Pediatric AIDS Foundation, US Agency for International Development Basic Support for Institutionalizing Child Survival Project (USAID/BASICS), US President's Emergency Plan for AIDS Relief (PEPFAR) 


\section{HIV AND AIDS}

Bhuiya, Ismat, Sharif Mohammed Ismail Hossain, Asiful Haider Chowdhury, K.M. Zahiduzzaman, and Syeda Tonima Hadi. "Blood supply and transfusion services," in Bangladesh Health Watch Report 2009: How Healthy Is Health Sector Governance. Dhaka: Bangladesh Health Watch, pp. 70-79.

Birungi, Harriet, Chi-Chi Undie, and Peter Aggleton. "Recent research on sexuality in East Africa," Culture, Health and Sexuality 11(8): 747-750.

Brown, Lisanne, Tonya R. Thurman, Janet Rice, Neil W. Boris, Joseph Ntaganira, Laetitia Nyirazinyoye, Jean De Dieu, and Leslie Snider. "Impact of a mentoring program on psychosocial wellbeing of youth in Rwanda: Results of a quasi-experimental study," Vulnerable Child and Youth Studies 4(4): 288-299.

Odimegwu, Clifford and Christian N. Okemgbo. 2008. "Men's perceptions of masculinities and sexual health risks in Igboland, Nigeria," International Journal of Men's Health 7(1): 21-39.

Okal, Jerry, Stanley Luchters, Scott Geibel, Matthew F. Chersich, Daniel Lango, and Marleen Temmerman. "Social context, sexual risk perceptions and stigma: HIV vulnerability among male sex workers in Mombasa, Kenya," Culture, Health and Sexuality 11(8): 811-826.

Onyango-Ouma, Washington, Harriet Birungi, and Scott Geibel. "Engaging men who have sex with men in operations research in Kenya," Culture, Health and Sexuality 11(8): 827-839.

Saggurti, Niranjan, Stephen L. Schensul, and Ravi K. Verma. "Migration, mobility and sexual risk behavior in Mumbai, India: Mobile men with non-residential wife show increased risk," AIDS and Behavior 13(5): 921-927.

Sarna, Avina, Matthew F. Chersich, Jerry Okal, Stanley Luchters, Kishorchandra N. Mandaliya, Naomi Rutenberg, and Marleen Temmerman. "Changes in sexual risk taking with antiretroviral treatment: Influence of context and gender norms in Mombasa, Kenya," Culture, Health and Sexuality 11(8): 783-797.

Speidel, J. Joseph, Deborah C. Weiss, Sally A. Ethelston, and Sarah M. Gilbert. "Population policies, programmes and the environment," Philosophical Transactions of the Royal Society of London, Series B, Biological Sciences 364(1532): 3049-3065.

Summers, Fiona (producer) and Barbara A. Friedland (executive producer). "Microbicides trials in your community," video. Cape Town and New York: Paw Print Productions and Population Council.

Undie, Chi-Chi, Abdhalah Kasiira Ziraba, Nyovani Janet Madise, John Kebaso, and Elizabeth Kimani-Murage. "'If you start thinking positively, you won't miss sex': Narratives of sexual (in)activity among people living with HIV in Nairobi's informal settlements," Culture, Health and Sexuality 11(8): 767-782.

Vagenas, Panagiotis, Vennansha G. Williams, Michael Piatak Jr., Julian W. Bess Jr., Jeffrey D. Lifson, James Blanchard, Agegnehu Gettie, and Melissa Robbiani. "Tonsillar application of AT-2 SIV affords partial protection against rectal challenge with SIVmac239," Journal of Acquired Immune Deficiency Syndromes 52(4): 433-529.

\section{POVERTY, GENDER, AND YOUTH}

“The adolescent experience in-depth: Using data to identify and reach the most vulnerable young peopleGuatemala 2002/2006." New York: Population Council.

"The adolescent experience in-depth: Using data to identify and reach the most vulnerable young peopleZambia 2007." New York: Population Council.

Amin, Sajeda. "Empowering adolescent girls in rural Bangladesh: Kishori Abhijan," in S. Jaya Krishna and
Naveen Kumar (eds.), Rural Empowerment: Indian and Global Initiatives. Hyderabad, India: Icfai University

Amin, Sajeda and Luciana Suran. "Terms of marriage and time-use patterns of young wives: Evidence from rural Bangladesh," Electronic Journal of Time Use Research 6(1): 92-108.

Assaad, Ragui and Ghada Barsoum. "Measurement and operationalization of job quality in Egypt," Gender and Work in the MENA Region Working Papers Series no. 1. Cairo: Population Council.

. "Rising expectations and diminishing opportunities for Egypt's young," in Navtej Dhillon and Tarik Yousef (eds.), Generation in Waiting: The Unfulfilled Promise of Young People in the Middle East. Washington, DC: Brookings Institution Press, pp. 67-94.

Assaad, Ragui, Ghada Barsoum, Emily Cupito, and Daniel Egel. "Addressing Yemen's twin deficits: Human development and natural resources," in Navtej Dhillon and Tarik Yousef (eds.), Generation in Waiting: The Unfulfilled Promise of Young People in the Middle East. Washington, DC: Brookings Institution Press, pp. 211-239.

Barsoum, Ghada, Ali Rashed, and Dahlia Hassanein. "When there is no respect at work: Job quality issues for women in Egypt's private sector," Gender and Work in the MENA Region Working Papers Series. Cairo: Population Council.

Bongaarts, John. "Human population growth and the demographic transition," Philosophical Transactions of the Royal Society of London, Series B, Biological Sciences 364(1532): 2985-2990.

"Trends in senescent life expectancy,"

Population Studies 63(3): 203-213.

Bongaarts, John, François Pelletier, and Patrick Gerland. "Global trends in AIDS mortality," Poverty, Gender, and Youth Working Paperno. 16. New York: Population Council.

Bongaarts, John and Steven W. Sinding. "A response to critics of family planning programs [Authors' reply]," International Perspectives on Sexual and Reproductive Health 35(3): 153-154.

Brady, Martha, J. Simbaya, Allison Stone, and Maya Vaughan-Smith. "Understanding adolescent girls" protection strategies against HIV: An exploratory study in Zambia." New York: Population Council.

Bruce, Judith and John Bongaarts. "The new population challenge," in Laurie Mazur (eds.), A Pivotal Moment Population, Justice, and the Environmental Challenge. Washington, DC: Island Press, pp. 260-275.

Community-Based Health Planning and Services (CHPS): Community Health Volunteers Training Manual. Accra: Population Council and Ministry of Health/Ghana Health Service.

Community-Based Health Planning and Services (CHPS) Community Health Officer Training Manual (Facilitator's Guide), Volume 1. Accra: Population Council and Ministry of Health/Ghana Health Service.

Community-Based Health Planning and Services (CHPS): Community Health Officer Training Manual (Facilitator's Guide), Volume 2. Accra: Population Council and Ministry of Health/Ghana Health Service.

Community-Based Health Planning and Services (CHPS): Community Health Officer Training Manual (Facilitator's Guide), Volume 3. Accra: Population Council and Ministry of Health/Ghana Health Service.

Community-Based Health Planning and Services (CHPS): Community Health Officer Registers-Instruction Manual. Accra: Population Council and Ministry of Health/Ghana Health Service.

Community-Based Health Planning and Services (CHPS):
Community Health Officer's Training Workbook, Volume 1. Accra: Population Council and Ministry of Health/ Ghana Health Service.

Community-Based Health Planning and Services (CHPS): Community Health Officer's Training Workbook, Volume 2. Accra: Population Council and Ministry of Health/ Ghana Health Service.

Community-Based Health Planning and Services (CHPS) Community Health Officer's Training Workbook, Volume

3. Accra: Population Council and Ministry of Health/ Ghana Health Service.

Community-Based Health Planning and Services (CHPS): Preceptor's Guide for Community Health Nursing Training Schools, Volume 1. Accra: Population Council and Ministry of Health/Ghana Health Service.

Community-Based Health Planning and Services (CHPS): Preceptor's Guide for Community Health Nursing Training Schools, Volume 2. Accra: Population Council and Ministry of Health/Ghana Health Service.

Community-Based Health Planning and Services (CHPS): Preceptor's Guide for Community Health Nursing Training Schools, Volume 3. Accra: Population Council and Ministry of Health/Ghana Health Service.

Community-Based Health Planning and Services (CHPS) Tutor's Guide for Community Health Nursing Training Schools, Volume 1. Accra: Population Council and Ministry of Health/Ghana Health Service.

Community-Based Health Planning and Services (CHPS): Tutor's Guide for Community Health Nursing Training Schools, Volume 2. Accra: Population Council and Ministry of Health/Ghana Health Service.

Community-Based Health Planning and Services (CHPS):

Tutor's Guide for Community Health Nursing Training

Schools, Volume 3. Accra: Population Council and

Ministry of Health/Ghana Health Service.

Das, Maitreyi and Sajeda Amin. “Marriage continuity and change in Bangladesh," in Ravinder Kaur, Shalini Grover, and Rajni Palriwala (eds.), Marriage in South Asia. New Dehli: Orient Blackswan.

"An executive summary of the primary health improvement initiative health systems assessment at commune level: Lessons from five provinces in Vietnam, 2004-2008," Population Council Viet Nam (PCVN) Brief. Hanoi: Population Council.

Ferede, Abebaw and Annabel Erulkar. "Adolescent girls in urban Ethiopia: Vulnerability and opportunity." Addis Ababa: Population Council.

Home Management of Malaria, Acute Respiratory Infection and Diarrhoea in Ghana: Implementation Guidelines. Accra: Population Council and Ministry of Health/Ghana Health Service.

Home Management of Malaria, Acute Respiratory Infection and Diarrhoea in Ghana: Manual for Community Based Agents. Accra: Population Council and Ministry of Health/Ghana Health Service.

“Innovative approaches to strengthen health management and information system," Vietnam-US Magazine, September (Special English Suppl. for Vietnam's Presidency in the UN Security Council New York Meeting and the Vietnam Investment Forum): 38-39. International Institute for Population Sciences (IIPS) and Population Council. "Youth in India: Situation and Needs 2006-2007, executive summary, Bihar." Mumbai: IIPS. (also available in Hindi)

"Youth in India: Situation and Needs 2006-2007, Bihar," report. Mumbai: IIPS.

"Youth in India: Situation and Needs 2006-2007 executive summary, Jharkhand." Mumbai: IIPS. (also available in Hindi)

“Youth in India: Situation and Needs 2006-2007, Tamil Nadu," report. Mumbai: IIPS. 
"Youth in India: Situation and Needs 2006-2007, executive summary, Tamil Nadu." Mumbai: IIPS. (also available in Tamil)

"Youth participation in civil society and politica life in Jharkhand," Youth in India: Situation and Needs Policy Brief no. 7. Mumbai: IIPS

"Transition to marriage and parenthood among youth in Jharkhand," Youth in India: Situation and Needs Policy Brief no. 8. Mumbai: IIPS

"Ensuring education for all in Jharkhand: Highlighting the obstacles," Youth in India: Situation and Needs Policy Brief no. 9. Mumbai: IIPS.

"Romance and sex before marriage among young women and men in Jharkhand," Youth in India: Situation and Needs Policy Brief no. 10. Mumbai: IIPS.

"Transition to work roles among youth in Jharkhand," Youth in India: Situation and Needs Policy Brief no. 11. Mumbai: IIPS

"Violence within marriage among young people in Tamil Nadu," Youth in India: Situation and Needs Policy Brief no. 12. Mumbai: IIPS.

"Education and transition to work among youth in Tamil Nadu," Youth in India: Situation and Needs Policy Brief no. 13. Mumbai: IIPS.

- "Sexuality education matters: Experiences of youth in Tamil Nadu," Youth in India: Situation and Needs Policy Brief no. 14. Mumbai: IIPS.

- "Youth participation in civil society and politica life in Tamil Nadu," Youth in India: Situation and Needs Policy Brief no. 15. Mumbai: IIPS.

"Youth participation in civil society and politica life in Bihar," Youth in India: Situation and Needs Policy Brief no. 16. Mumbai: IIPS.

"Transition to work roles among youth in Bihar," Youth in India: Situation and Needs Policy Brief no. 17. Mumbai: IIPS

. "Transition to marriage and parenthood among youth in Bihar," Youth in India: Situation and Needs Policy Brief no. 18. Mumbai: IIPS.

. "Romance and sex before marriage among young women and men in Bihar," Youth in India: Situation and Needs Policy Brief no. 19. Mumbai: IIPS.

"Ensuring education for all in Bihar: Highlighting the obstacles," Youth in India: Situation and Needs Policy Brief no. 20. Mumbai: IIPS.

Kifle, Elshaday, Mekuria Yilma, and Emil Parker. "Directory of programs for rural girls in Ethiopia." Addis Ababa: Population Council.

Lloyd, Cynthia B. New Lessons: The Power of Educating Adolescent Girls -A Girls Count Report on Adolescent Girls. New York: Population Council.

Mensch, Barbara S., Paul C. Hewett, Heidi E. Jones, Carla G. Luppi, Sheri A. Lippman, Adriana A. Pinho, and Juan Diaz. “Consistencia lógica de la información aportada por mujeres sobre conductas sensibles: Resultados de un experimento realizado con dos modos de entrevista, São Paulo, Brasil," International Family Planning Perspectives 35(Número Especial de 2009): 21-29.

"Pakistan's demographic transition in the development context." Islamabad: Population Council.

Princess Savings Account frequently asked questions. Nairobi: Faulu Kenya Limited.

Santhya, K.G. “Making pregnancy safe for women in Rajasthan: Targeting the most vulnerable," Policy Brief no. 1. New Delhi: Population Council.

"Strengthening the health information management system in Thai Nguyen," Vietnam-US Magazine, JulyAugust: 20-21.

Thu Ha, Tran, Ruth Lavergne, Jane Hughes, and Meiwita Budiharsana. "Primary health improvement initiative, micro-pilot use of evidence computerized data entry system at commune health centers: Lessons learned." Hanoi: Population Council.

Vaid, Monisha. "Exploring the lives of youth in the BPO sector: Findings from a study in Gurgaon," Health and
Population Innovation Fellowship Programme Working Paperno. 10. New Delhi: Population Council.

Washington, Maryann. "BEING (Becoming Empowered in Nursing Growth): Training guide for nursing students on sexuality and gender," Health and Population Innovation Fellowship Programme training guide. New Delhi: Population Council.

\section{REPRODUCTIVE HEALTH}

Anwar, Md. Mahabub UI, Aminul Arifeen, Ismat Ara Hena, and Md. Mafizur Rahman. "Increasing the rational use of modern contraceptive methods during reproductive life cycle." Dhaka: Population Council. "APHIA II Operations Research Project in Kenya," brochure. Nairobi: Population Council.

Cheng, Chuen-yan and Dolores D. Mruk. “An intracellular trafficking pathway in the seminiferous epithelium regulating spermatogenesis: A biochemica and molecular perspective," Critical Reviews in Biochemistry and Molecular Biology 44(5): 245-263.

. "Regulation of blood-testis barrier dynamics

by focal adhesion kinase (FAK): An unexpected turn of events," Cell Cycle 8(21): 3493-3499.

“Current Population Council projects on emergency contraception," fact sheet. New York: Population Council.

Diop, Nafissatou J. et.al. 2008. “Analyse de la situation du condom féminin au Sénégal." UNFPA and Ministry of Health.

. 2008. "Plan stratégique du condom féminin au Sénégal." UNFPA, Ministry of Health, and Population Council.

Diop, Nafissatou J., Ida Sawadogo, and M. Konate. 2008. Analyse de la situation du condom féminin au Burkina Faso." Population Council, UNFPA, Republic of Burkina Faso.

Diop, Nafissatou J., Geetor Saydee, and Nyakpu Taylor. 2008. "National strategic plan for comprehensive condom programming in Liberia, 2009-2013." Population Council, UNFPA, and Ministry of Health.

- 2008. "Situation analysis of condoms in Liberia. Population Council, UNFPA, and Ministry of Health.

"Emergency contraception: Addressing unwanted pregnancies and maternal mortality in Senegal," fact sheet. New York: Population Council.

"Emergency contraception in South Asia," The Inside Story: Turning Research into Policy and Practice no. 1. New Delhi: Population Council.

Hong, Dun, Xing-Wang Li, Qing-Quan Lian, Pankaj Lamba, Daniel J. Bernard, Dianne 0. Hardy, Hai-Xiao Chen, and Renshan Ge. "Mono-(2-ethylhexyl) phthalate (MEHP) regulates glucocorticoid metabolism through

$11 ß$-hydroxysteroid dehydrogenase 2 in murine gonadotrope cells," Biochemical and Biophysical Research Communication 389(2): 305-309.

"International family planning programs: A fact sheet." New York: Population Council.

Keesbury, Jill, Hailegiorgis Aytenfisu, and Spike Bradford. "Mainstreaming emergency contraception in Ethiopia's public sector," Ethiopian Journal of Public Health.

Keesbury, Jill, Mary Zama, and Sudha Shreeniwas.

"The copperbelt model of integrated care for survivors of rape and defilement: Testing the feasibility of police provision of emergency contraceptive pills." Lusaka: Population Council.

Kopera, Ilona A., Linlin Su, Barbara Bilinska, Chuenyan Cheng, and Dolores D. Mruk. "An in vivo study on adjudin and blood-testis barrier dynamics," Endocrinology 150(10): 4724-4733.

Lee, Nikki P.Y. and Chuen-yan Cheng. "Nitric oxide and cyclic nucleotides: their roles in junction dynamics and spermatogenesis," Advances in Experimental Medicine and Biology 636: 172-185.

Li, Michelle W.M., Dolores D. Mruk, Will M. Lee, and Chuen-yan Cheng. "Disruption of the blood-testis barrier integrity by bisphenol $A$ in vitro: Is this a suitable model for studying blood-testis barrier dynamics?" International Journal of Biochemistry and Cell Biology 41(11): 2302-2314.

Liambila, Wilson, Ian Askew, Juma Mwangi, Robert Ayisi, Josephine Kibaru, and Saiqa Mullick. "Feasibility and effectiveness of integrating provider-initiated testing and counselling within family planning services in Kenya," AIDS 23(suppl 1): S115-S121.

Lui, Wing-Yee and Chuen-yan Cheng. "Transcription regulation in spermatogenesis," Advances in Experimental Medicine and Biology 636: 115-132.

Mutahara, Marium ul, Md. Mafizur Rahman, and Ahmed Al-Sabir. "Creating a space for men and youth at health and family welfare centers in Bangladesh." Dhaka: Population Council.

Mwangi, Gladys K. and Guyo Jaldesa. “An assessment of sexual and gender based violence in Wajir district, North Eastern Kenya." Nairobi: Population Council.

Obare, Francis, Harriet Birungi, Anne Katahoire, Hannington Nkayivu, and Aggrey David Kibenge. "Special needs of in-school HIV positive young people in Uganda." Nairobi: Population Council.

Obare, Francis, Jill Keesbury, and Wilson Liambila "The provision of emergency contraceptives in private sector pharmacies in urban Kenya: Experiences of mystery clients," African Population Studies 24(1).

Ranade, Ketki. "Medical response to male same-sex sexuality in western India: An exploration of 'conversion treatments' for homosexuality," Health and Population Innovation Fellowship Programme Working Paper no. 8. New Delhi: Population Council.

Siu, Michelle K.Y. and Chuen-yan Cheng. "Extracellula matrix and its role in spermatogenesis," Advances in Experimental Medicine and Biology 636: 74-91.

Sujay, Rachna. “Premarital sexual behaviour among unmarried college students of Gujarat, India," Health and Population Innovation Fellowship Programme Working Paperno. 9. New Delhi: Population Council.

Sun, Shengyi, Elissa W.P. Wong, Michelle W.M. Li, Will M. Lee, and Chuen-yan Cheng. "14-3-3 and its binding partners are regulators of protein-protein interactions during spermatogenesis," Journal of Endocrinology 202(3): 327-336.

Talukder, Md. Noorunnabi and Ubaidur Rob.

"Strengthening voice and accountability in the health sector." Dhaka: Population Council.

Wong, Elissa W.P. and Chuen-yan Cheng. "Polarity proteins and cell-cell interactions in the testis," International Review of Cellular Molecular Biology 278 $309-353$.

Wong, Elissa W.P., Shengyi Sun, Michelle W.M. Li, Will M. Lee, and Chuen-yan Cheng. "14-3-3 protein regulates cell adhesion in the seminiferous epithelium of rat testes," Endocrinology 150(10): 4713-4723.

Yan, Helen H., Dolores D. Mruk, Will M. Lee, and Chuenyan Cheng. "Cross-talk between tight and anchoring junctions: Lesson from the testis," Advances in Experimental Medicine and Biology 636: 234-254.

\section{OTHER PUBLICATIONS}

"ACASI software technical notes," brochure. New York: Population Council.

"Audio computer-assisted self-interviewing (ACASI)," fact sheet. New York: Population Council.

“Adolescent girls," Momentum, December 2009. New York: Population Council.

Population and Development Review 35(4)

Studies in Family Planning 40(4) 


\section{Contraceptive Research Leads to an Array of Options}

The introduction of the contraceptive pill in the early 1960s launched a revolution in family planning. Since then, innovative birth control methods - including long-term hormonal injectables, intrauterine devices, hormonal implants, and hormonal vaginal rings and skin patches - have further expanded options for women who want to postpone childbearing or space their births.

Yet despite this enormous progress, incorrect use or lack of use still accounts for too many unintended pregnancies. In the United States, for instance, approximately 1.5 million pregnancies — over half of all unintended pregnancies - occur in women who use contraception; 90 percent of these unintended pregnancies are attributed to inconsistent or incorrect use of a contraceptive method. Lack of access also contributes to unintended pregnancies. According to the Population Reference Bureau's most recent data, 1.7 billion women worldwide were in need of contraception in 2007, but only 57 percent of them were using modern methods.

A paper by Population Council researchers Ruth Merkatz, Régine Sitruk-Ware, and Barbara Tokay of the Population Council's Center for Biomedical Research traces the evolution of contraceptive methods and suggests that development of modern contraceptive methods may be relevant to development of therapeutics for chronic medical conditions and that novel contraceptive methods can be used as models for innovation in drug delivery systems.

\section{Decades of improvements bring new delivery methods}

After the oral contraceptive pill was introduced in the early 1960s, the method quickly became the gold standard, with a low 8 percent pregnancy rate based on real-life use. In clinical trials the pregnancy rate was lower than 1 percent. Concern about side effects from this method led to modifications, most notably a significant reduction in the dose of estrogen, development of new synthetic progestins, and, ultimately, development of new ways to deliver trel-releasing intrauterine system; Jadelle $^{\circledR}$, a two-rod levonorgestrel implant; and Norplant ${ }^{\circledR}$ implants. The Council is completing development of a new vaginal ring that can be re-used for up to one year.

Although improvements in methods have contributed to the increased use of contraception worldwide, current user-controlled methods

\section{ADVANCES IN CONTRACEPTIVE TECHNOLOGY}

\section{0s — oral contraceptives \\ 1970s - Copper T intrauterine devices \\ 1980s — first subdermal implants \\ 1990s — first hormonal intrauterine system 2000s — vaginal rings, transdermal patch}

these hormonal drugs. Eventually scientists bypassed the oral route altogether, with several innovative systems, such as vaginal rings and skin patches, allowing scientists to use smaller amounts to greater effect. At the same time, they modified pill regimens and refined hormonal ingredients to minimize the side effects of oral contraceptives, thereby creating many more contraceptive options.

The Population Council has developed and licensed some of the most widely used longacting, reversible contraceptives in the world, notes Sitruk-Ware, who is executive director for reproductive health research and development at the Council's Center for Biomedical Research. More than 100 million women worldwide rely on Population Council-developed products for family planning, which include copper-bearing intrauterine devices; Mirena ${ }^{\circledR}$, a levonorges- could be further improved to promote proper usage. "Contraceptive development remains challenging, given that the methods not only must be safe, but also acceptable to the user and effective for long periods of time," says Merkatz, who is director of clinical development for reproductive health at the Council's Center for Biomedical Research.
SOURCE

Merkatz, R.B., B. Tokay, and R.L. Sitruk-Ware. 2009. "Methods for female contraception: A model for innovation in drug delivery systems," Clinical Pharmacology \& Therapeutics 85(5): 553-557.

\section{OUTSIDE FUNDING}

CONRAD, Donations from foreign governments, The Lita Annenberg Hazen Foundation, George J. Hecht Funds, William and Flora Hewlett Foundation, National Institute of Child Health and Human Development, United Nations Population Fund, US Agency for International Development, World Health Organization 